\title{
Ćwiczenia fizyczne jako czynnik zapobiegający nowotworom i poprawiający rokowanie: dobrze udokumentowana metoda
}

\author{
Renata Duchnowska
}

Aktywność fizyczna i utrzymanie należnej masy ciała, obok niepalenia tytoniu, są uważane za najważniejszy czynnik w profilaktyce najczęstszych nowotworów. Co więcej, aktywność fizyczna coraz częściej jest postrzegana jako „niefarmakologiczna" metoda zwalczania fizjologicznych i psychologicznych następstw leczenia. Wyniki ostatnich badań sugerują wiele korzyści z aktywności fizycznej podczas leczenia onkologicznego i po jego zakończeniu.

\section{Physical activity is a well documented factor in prevention of the most common cancers}

Physical activity and maintaining proper body mass, in addition to smoking cessation, are considered to be important factors in prevention of the most common cancers. Furthermore, physical activity has been increasingly researched as a non-pharmacological intervention to combat the physiologic and psychological effects of treatment in cancer patients. Current evidence suggests many health benefits from physical activity during and post cancer treatments.

NOWOTWORY J Oncol 2016; 66, 3: 251-253

Słowa kluczowe: ćwiczenia fizyczne, nowotwory, otyłość, nadwaga

Key words: physical activity, neoplasms, obesity, overweight

\section{Wstęp}

Nadwaga i otyłość stają się plagą XXI wieku. Światowa Organizacja Zdrowia (WHO) szacuje, że w latach 1980-2013 odsetek osób o wskaźniku masy ciała (BMI — body mass index) $\geq 25-30 \mathrm{~kg} / \mathrm{m}^{2}$ wzrósł z $29 \%$ do $37 \%$ u mężczyzn i z 30\% do 38\% u kobiet [1]. W jeszcze większym stopniu problem nadwagi i otyłości dotyczy dzieci i młodzieży. Główną przyczyną tego zjawiska jest tzw. leniwy styl życia, czyli mała aktywność fizyczna oraz złe nawyki żywieniowe. Konsekwencjami nadwagi, a zwłaszcza otyłości, są zaburzenia metaboliczne prowadzące do hiperinsulinemii, wzrostu stężenia insulinopodobnego czynnika wzrostu, leptyny i wykładników stanu zapalnego, oraz hiperestrogenizm [2].

\section{Ćwiczenia fizyczne jako czynnik zapobiegający nowotworom}

Związek pomiędzy nadwagą i otyłością a zwiększonym ryzykiem zachorowania na niektóre nowotwory, w szczegól- ności raki przewodu pokarmowego, piersi, narządu rodnego, gruczołu krokowego i nerki, wykazano w licznych badaniach [3-5]. Aktywność fizyczna i utrzymanie należnej masy ciała, obok niepalenia tytoniu, są zatem uważane za najważniejszy czynnik w profilaktyce najczęstszych nowotworów.

Według danych American Institute for Cancer Research zaledwie połowa społeczeństwa jest świadoma tych zagrożeń (www.aicr.org). Co gorsza, jedynie 50\% społeczeństwa stosuje się do wytycznych WHO, które zalecają u dorosłych w wieku 18-64 lat utrzymanie tygodniowej aktywności fizycznej na poziomie co najmniej 2,5 godziny oraz wykonywanie 2 lub 3 razy w tygodniu ćwiczeń zwiększających siłę mięśni i wytrzymałość (www.cdc.gov; www.who.int).

\section{Ćwiczenia fizyczne jako czynnik poprawiający rokowanie u chorych na nowotwory}

W dwóch opublikowanych przeglądach systematycznych i metaanalizie badań obserwacyjnych, obejmujących 
głównie chorych na raka piersi i jelita grubego po radykalnym leczeniu, wykazano, że aktywność fizyczna zmniejsza ryzyko zgonu ogółem i z powodu nowotworu [6, 7]. W poszczególnych badaniach stosowano różne metody i kryteria pomiaru aktywności fizycznej — od 9 do 27 MET (metabolic equivalent time)-godz./tydzień (co odpowiada 30-75 min szybkiego marszu 5 razy w tygodniu) przed radykalnym leczeniem onkologicznym, w jego trakcie i po zakończeniu. Stwierdzono również, że zwiększenie aktywności fizycznej po rozpoznaniu zmniejsza w stosunku do okresu przed rozpoznaniem względne ryzyko zgonu o około $40 \%$ (HR =0,61; 95\% Cl: 0,46-0,80) [7]. Podobne obserwacje w odniesieniu do chorych na raka gruczołu krokowego pochodzą z Health Professional Follow-Up Study [8]. Umiarkowana aktywność fizyczna: jazda na rowerze, gra w tenisa, joga czy pływanie co najmniej 3 godziny w tygodniu znacząco zmniejszała ryzyko zgonu z powodu tego nowotworu ( $\mathrm{HR}=0,39 ; \mathrm{p}=0,03)[8]$. $Z$ kolei w innym badaniu obserwacyjnym (Cancer of the Prostate Strategic Urologic Research Endeavor) wykazano, że u chorych na miejscowo zaawansowanego raka gruczołu krokowego stopień wysiłku fizycznego - tempo marszu poniżej lub powyżej trzech mil na godzinę; wiązał się ze zmniejszeniem o połowę ryzyka progresji (HR=0,52; 95\% Cl: 0,29-0,91; $\mathrm{p}$ (trend) =0,01) [9].

$\mathrm{U}$ chorych na rozsiane nowotwory wpływ aktywności fizycznej na rokowanie był przedmiotem nielicznych badań prospektywnych. W jednym z nich, dotyczącym chorych na zaawansowanego niedrobnokomórkowego raka płuca w stanie sprawności 0-3 w skali ECOG (Eastern Cooperative Oncology Group), wykazano, że poza osiągnięciem dłuższego dystansu w teście 6-minutowego marszu, również deklarowana aktywność fizyczna: powyżej lub poniżej 9 MET-godz./tydzień, wiązała się z dłuższą medianą całkowitego czasu przeżycia (odpowiednio 26 i 13 miesięcy) [10].

Opublikowana w 2010 r. metaanaliza 66 badań $(90 \%$ z randomizacją i 10\% z grupą kontrolną), obejmująca łącznie ponad 6 tysięcy chorych, wykazała pozytywny wpływ ćwiczeń fizycznych podczas i po zakończeniu leczenia na poprawę siły mięśniowej, sprawności fizycznej, samooceny, sylwetki, jakości życia oraz witalności [11]. Podobnie jak w badaniach obserwacyjnych, metaanaliza ta w większości (83\%) dotyczyła chorych na raka piersi; pozostałą część stanowili chorzy na raka jelita grubego, płuca, jajnika, gruczołu krokowego, żołądka, jądra oraz nowotwory układu krwiotwórczego i limfatycznego. W większości badań w grupie doświadczalnej stosowano aerobik w natężeniu od umiarkowanego do intensywnego oraz trening siły mięśniowej w trakcie lub po zakończeniu leczenia, 3-5 razy w tygodniu przez 30-45 minut, w czasie od 5 tygodni do 3 miesięcy. Podobne korzystne wyniki dotyczące ćwiczeń fizycznych pochodzą z innych badań oraz kolejnej metaanalizy badań z randomizacją z 2012 roku [12-15]. W badaniach tych wykazano również, że ćwiczenia fizyczne zmniejszają odczuwanie bólu, zmęczenia i innych niepożądanych objawów związanych z leczeniem oraz wpływają na poprawę wskaźników odpowiedzi immunologicznej, obniżenie stężenia wykładników stanu zapalnego oraz szlaku metabolicznego insuliny [12-14]. Dodatkowo ćwiczenia fizyczne zmniejszały objawy chorób współistniejących, np. układu krążenia, oraz obniżały ryzyko osteoporozy i cukrzycy. Ćwiczenia fizyczne nie zwiększały przy tym nasilenia objawów niepożądanych, również u chorych z obrzękiem limfatycznym kończyny górnej, niedokrwistością i po przeszczepie komórek macierzystych [12-14].

Wpływ ćwiczeń fizycznych na czas do nawrotu i czas przeżycia u chorych na raka piersi i jelita grubego po radykalnym leczeniu jest przedmiotem toczących się obecnie badań z randomizacją: START (Supervised Trial of Areobic versus Resistance Training) i CHALLENGE (The Colon Health and Life-Long Exercise Change) [16-18].

\section{Podsumowanie}

Wyniki dotychczasowych badań obserwacyjnych i doświadczalnych wskazują, że ćwiczenia fizyczne są dobrze udokumentowaną metodą zapobiegającą nowotworom i poprawiającą rokowanie. Umiarkowany do intensywnego aerobik w połączeniu z treningiem siły mięśniowej są zalecane przez towarzystwa naukowe: American Cancer Society, American College of Sports Medicine, British Association of Sport and Exercise Science, Comprehensive Cancer Center the Netherlands, Exercise and Sport Science Australia oraz American Society of Clinical Oncology [19]. Ćwiczenia fizyczne u chorych na nowotwory na pewno nie szkodzą i są bezpieczne. W zaleceniach lekarskich należy poinformować chorego o potrzebie utrzymania należnej masy ciała poprzez stopniowe zwiększanie aktywności fizycznej do zalecanych w grupie wiekowej 18-65 lat (150 minut w tygodniu) oraz potrzebie treningu siły mięśniowej i wytrzymałości. U wybranych chorych ćwiczenia fizyczne powinny być prowadzone pod nadzorem rehabilitantów.

Konflikt interesów: nie zgłoszono

Dr hab. n. med. Renata Duchnowska

Klinka Onkologii

Wojskowy Instytut Medyczny w Warszawie

ul. Szaserów 128, 04-141 Warszawa

e-mail:rdtt@wp.pl

Otrzymano i przyjęto do druku: 9 maja $2016 r$.

Na podstawie wystąpienia podczas IV Konferencji Naukowej czasopisma Nowotwory „Debaty onkologiczne”, 8-9 kwietnia 2016 r.

\section{Piśmiennictwo}

1. Ng M, Fleming $T$, Robinson $M$ i wsp. Global, regional, and national prevalence of overweight and obesity in children and adults during 1980-2013: a systematic analysis for the Global Burden of Disease Study 2013. Lancet 2014; 384: 766-781. 
2. Baranowska B, Krzyżanowska-Świnarska B. Zaburzenia odżywiania. W: Szczeklik A (red.) Choroby wewnętrzne. Stan wiedzyna rok 2010, Kraków: Medycyna Praktyczna, 2010; 1285-1294.

3. Fontham ET, Thun MJ, Ward E i wsp. American Cancer Society perspectives on environmental factors and cancer. CA Cancer J Clin 2009; 59: 343-351.

4. Demark-Wahnefried W, Platz EA, Ligibel JA i wsp. The role of obesity in cancer survival and recurrence. Cancer Epidemiol Biomarkers Prev 2012; 21: 1244-1259.

5. Dobbins M, Decorby K, Choi BC. The Association between Obesity and Cancer Risk: A Meta-Analysis of Observational Studies from 1985 to 2011. ISRN Prev Med 2013; 2013: 680536.

6. Ballard-Barbash R, Friedenreich CM, Courneya KS i wsp. Physical activity, biomarkers, and disease outcomes in cancer survivors: a systematic review. J Nat/ Cancer Inst 2012; 104: 815-840.

7. Schmid D, Leitzmann MF. Association between physical activity and mortality among breast cancer and colorectal cancer survivors: a systematic review and meta-analysis. Ann Oncol 2014; 25: 1293-1311.

8. Kenfield SA, Stampfer MJ, Giovannucci E i wsp. Physical activity and survival after prostate cancer diagnosis in the health professionals follow-up study. J Clin Oncol 2011; 29: 726-732.

9. Richman EL, Kenfield SA, Stampfer MJ i wsp. Physical activity after diagnosis and risk of prostate cancer progression: data from the cancer of the prostate strategic urologic research endeavor. Cancer Res 2011; 71: 3889-3895.

10. Jones LW, Hornsby WE, Goetzinger A i wsp. Prognostic significance of functional capacity and exercise behavior in patients with metastatic non-small cell lung cancer. Lung Cancer 2012; 76: 248-252.
11. Speck RM, Courneya KS, Mâsse LC i wsp. An update of controlled physical activity trials in cancer survivors: a systematic review and meta-analysis. J Cancer Surviv 2010; 4: 87-100.

12. Demark-Wahnefried W, Rogers LQ, Alfano CM i wsp. Practical clinical interventions for diet, physical activity, and weight control in cancer survivors. CA Cancer J Clin 2015; 65: 167-189.

13. Baumann FT, Zopf EM, Bloch W. Clinical exercise interventions in prostate cancer patients - a systematic review of randomized controlled trials. Support Care Cancer 2012; 20: 221-233.

14. Sturgeon KM, Ky B, Libonati JR i wsp. The effects of exercise on cardiovascular outcomes before, during, and after treatment for breast cancer. Breast Cancer Res Treat 2014; 143: 219-226.

15. Fong DY, Ho JW, Hui BP i wsp. Physical activity for cancer survivors: meta-analysis of randomized controlled trials. BMJ 2012; 344: e70.

16. Courneya KS, Segal RJ, McKenzie DC i wsp. Effects of exercise during adjuvant chemotherapy on breast cancer outcomes. Med Sci Sports Exerc 2014; 46: 1744-1751.

17. Courneya KS, Booth CM, Gill S i wsp. The Colon Health and Life-Long Exercise Change trial: a randomized trial of the National Cancer Institute of Canada Clinical Trials Group. Curr Oncol 2008; 15: 279-285.

18. Courneya KS, Vardy J, Gill S i wsp. Update on the Colon Health and Life-Long Exercise Change Trial: A phase III study of the impact of an exercise program on disease-free survival in colon cancer survivors. Curr Colorectal Cancer Rep 2014; 10: 321-328.

19. Buffart LM, Galvão DA, Brug J i wsp. Evidence-based physical activity guidelines for cancer survivors: current guidelines, knowledge gaps and future research directions. Cancer Treat Rev 2014; 40: $327-$ $-340$ 